\title{
EMBRAPA: Institutional Building and Technological Innovations Required for Cerrado Agriculture
}

\author{
Elisen Alves
}

\section{Introduction}

A solid and highly effective institution was considered to be essential to achieve the required innovations for the development of Cerrado agriculture. In this regard, the Brazilian Agricultural Research Corporation (EMBRAPA) was the key entity in the establishment of a strong innovation system for Cerrado agriculture. Therefore, this chapter first discusses the main principles that guided EMBRARA and constituted the cote of the 'EMBRAPA model' (Section 6.1). This aspect is important to show that EMBRAPA was ready for mature cooperation with the government of Japan through $\| \mathrm{CA}$, which will be discussed later. A summary of the EMBRAPA development process in terms of researchers and different types of expenditures follows (Section 6.2). The policy of Cerrado agriculure development is briefly explained in order to clarify the role that EMBRAPA has been expected to accomplish in this context. The government of Brazil chose to develop the Cerrado, and policies targeting this goal encompassed agriculture, infrastructure, research, universities (especially graduate programs), and rural and urban infrastructure. It was an all-inclusive regional development program (Section 6.3). The chapter goes on to discuss what kind of external cooperation would have been most effective for EMBRAPA to accomplish such a role, focusing on the most important issues that needed to be taken into account in formulating EMBRAPA's institution building plan (Section 6.4). To deepen this analysis, Section 6.5 distinguishes two types of external cooperation from an institution building perspective: a 'folning institutions' type and a specialized type. In this regard, the results of cooperation should 
be assessed in terms of two aspects: (a) institution building by which the recipient institution becomes prepared to face present and fmure challenges; and (b) new technology developed through cooperation and its dissemination to famers. From this perspective, distinctive charactoristics of the EMBRAPA-Japan cooperation are discussed (Section 6.6). hinally, concluding remarks are presented (Section 6.7).

\subsection{The 'EMBRAPA model' and its main principles}

EMBRAPA's role is to be ready whin answers to society's problems in the lield of agriculure. As a researh institution, EMBRAPA has to answer to society quickly, because without prompt answers, mvestments will not be forthoming, or will soon be discontmued. Let us look into the fundamental principles that guided EMBRAPA's development.

For a research institute such as EMBRAPA to be successful, it showld have an organizational model that is flexible and free from bureaucratic burdens. The organization must be tree to fomulate, adjust and manage its budget, to select its priorities and carry out research, and to formulate and acminister its human resources policies; therefore, a public corporation model was chosen tor EMBRAPA according to the laws of Brazil. EMRRAPA's geographical scope was to encompass all of the national lerritory, and it was to carry out research copperation with other countries. Moreover, research requires competent resarchers, and so it was necessary to provide appropriate training and to pay competive wages. The mstitute's leadership needed to be an intemational level. To be productive, researchers need libraries and up-to-date laboratories, both of which had to be integrated with advanced global research centers. The recruiting and promotion of researchers had to be according to ment, based on objective evaluations. It was essential to establish a research career path that challenged talent, rewarded good work, and offered the conditions for comprehensive dedication to research. In researth, the scarcest resource is the researcher's time. Laboratories, libraries, and reseanch support all have the role of multiplying the researcher's time. Bureaucracy exercises an opposite effect, and for this reason it had to be minimized. The units of research (research centers) needed to effectively explain themselves to researchers and society; they had to avoid the dispersion of eftorts, and faciliate interaction among consumers, hamers, and agri-businesses.

To bllow these principles, EMBRAPA established national centers, cach of which took care of a limited number of previously established prionities. As a result, society, farmers, extension workers, and authorites 
all knew which center took care of what products, such as soybeans, com, rice, and beans, and which center was responsible for the Cerrado and advanced biology rescarch. This model facilitated the evaluation of successes and falures, and helped famers to discover the technologies and knowledge they wanted, and evaluations and promolons became comnected to the productive life of the researcher.

The organizational lines of authority are well defined in EMBRARA, and its directors are free to enforce the rules, without partisan or thirdparty interference. Research funding is drawn from the national treasury, and treasury and budget authorities had to be aware of the economic value of research relative to other investments. To communicate with the authorities, research instututions require economists with high-level training to establish communication channels in appropriate language, and the knowledge of research inpacts is crucial to show how research investments rank with altematives. Jounalists are also very imporant in terms of building a positive institutional image, and so they are at the same level of importance as the researchers themselves, and require training and resources to develop their work. Researchers must have access to the international research communily, and the research budget should finance international travel, joint projects with international scientists, and Internet use.

Research institutions do not grow without the support and respect of politicians, party leaders of different ideological shadings, consumers, and government authorities. Legislation should encourage partnerships for mutual benefit between public and private research, free from legal risk. Mnally, partisan politics and ideologies cannot dictate research priorities, research methods, and the choice of members of the board of directors.

\subsection{Development of EMBRAPA}

The above provided a condensed discussion of EMBRAPA's fundamental principles, which this section rounds out with data on the size of its labor force, expendiures, how it covers Brazil geographically, and its international agreements.

EMBRAPA's labor force includes researchers and research support personnel. There are also several types of arrangement, of a short-tem nature, aimed at training students and non-students, but only if they have recently graduated. The delailed data document researchers and research suppont personnel: those who have had long-term contracts with EMBRAPA. Although shorterm personnel are very important for 
EMBRAPAs work, their numbers fuctuate a great deal from month to month, and hence the discussion here concentrates on researchers and support employces.

We can divide the period from 1973 to 2010 into three sub-periods. In the 1973 - 1990 sub-period EMBRAPA expanded vigorously: its labor force grew conumuously to reach a peak in 1990 . Subsequently, there was a reduction in support personnel tor two reasons: first, the admin. istration chose more elicient methods to hande its support persond; and second, as a consequence of the economic crises, expenses had to be cut; in order to keep researchers, there was no other way than to reduce the number of support employees. This difficult perind lasted from 1990 to 2005 , which constitutes the second sub-period; recovery then lollowed in the luird submeriod, which contrumes to the present. As LMBRAPA responds to Btazils technology needs, its growth will advance at a slower pace than in the past, according to new demands.

EMBRADAs short-term personel are mainly students from the agraran science unversities, and part of their training must be undertaken ontside the university in research institutions or in the private sector. In the course of their training they carry out important work sumervised by sentor researchers. In 2010 , there were a total of 2,930 tranees, of Whom 355 were postgraduate students. In December 2010 EMBRAMA had 0.248 regular cmployees, and so the short-term persomel accounted for 32.1 percent, or about onewthid of its labor force (under contract).

Regarding researchers and support personel, Figure 6.1 illustrates the sub-periods noted above: vigorous grow of the labor force from 1973 to 1990; a severe cut in suppor personuel between 1990 and 2005 , with minor growth in the number of researchers; and a perod of recovery from 2006 to 2010 , at a pace appropriate for a mature institution where growth heeps pace with new demands.

In 1973, when LMBRAPA was inaugurated, the agrarian science universities graduated professionals at the Bachelor of Sciences (BSc) level only, but EMBRAPA required peopla with Master's degrees and Ph.D.s, and so it developed a vigorous program, in Brazil and abroad, to graduate researchers at the Master's and Mh.D. levels. The program was so successtul that a large majorty of EMBRAPA researchers were Wh.D.S by December 2010. The EMBRAPA graduate program now takes care of post-doctoral training, because Brazhian unversties offer high-quality training at the Master's and PL.D. level. As the market supplies high level tramed professionals to BMBRADA, or to any other instifutions that wish to hire them, there is no reason for EMBRAPA to invest in post. graduate traning, except in a limited number of cases. 


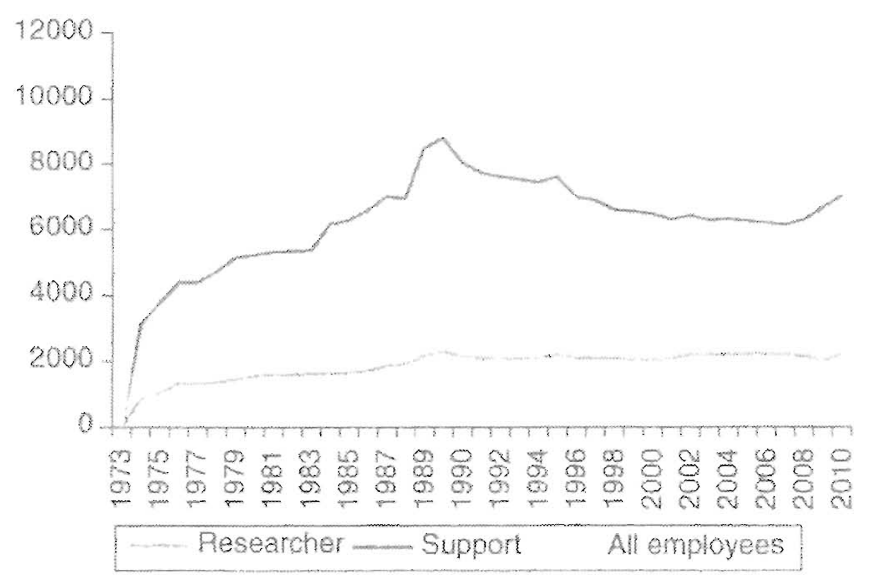

Fisure 6.1 Trends in the number of researchers, reseach support statt, and all comployees of EMBRADA

Seme: Author.

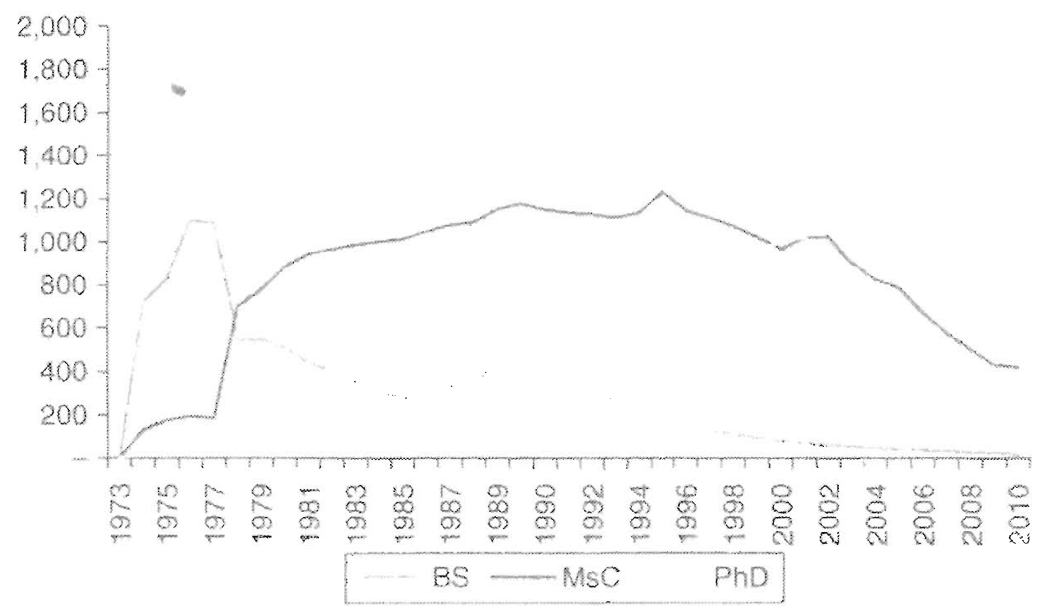

Figure 6.2 Number of researchers by graduate qualifications: BS, Master's, and Phis

Soure: Author.

In December 2010, EMBRAPA's labor force comprised 9,248 employees, split between 2,215 researchers (24 percent) and 7,033 research support personnel (76 percent). Of the researchers, 1,775 were th. D.5 (80.1 percent), 421 had Master's degrees (19.0 percent), and 19 were at 
the BS level 109 percent). The graphic shows that EMBRAPA's research staff are converging toward being Ph. D, only. Looking at these numbers, one can see the threesub-periods, the success of the training program, the cut in support persomel, and the preservation of researcher positions.

Hgure 6.3 shows the yearly vartation in the rate of EMBRAPA expendilures as a percentage of the GDP of the agricuture sector. The GDP share line traces the behavior of the actual rate over time. The other line shows an index rate equal to 1 percent, on the assumption that total expenditures on agricultural research as a share of the agricultural GDP should equal at least 1 percent. Since the data do not cover expenditures by state research institutions, federal universities and institutes, or privale sector reseanch organizations, this record shows Brazil to be in a lavorable posilion. There was vigorous and contmuous growth in EMBRARA's expendithres in its first decade, from its beginning to 1982, which was followed by a strong fall in 1983 and 1984 due to macro-economic adjusments. EMBRAPA's expenditures as a share of agricultural GDP then began to move up again and exceeded the I percent mark in 1991. In 1992 the share thpped, then rose again to reach the peak of the sentes in 1996. It stayed above the 1 pexcent mark in the period from 1995 to 2001 . Again due macro-economic adustments, EMBRAPA's expenditures as a share of agricultural GDP fell unth 2003 , and then moved up again to exceed 1 prenent in 2009 and 2010.

The data show that the govemment has tended to align the growth of EMBRAPA's budget to growth in the GDP of the agriculture sector. Dips in the level of expendirures were consequences of macro-economic

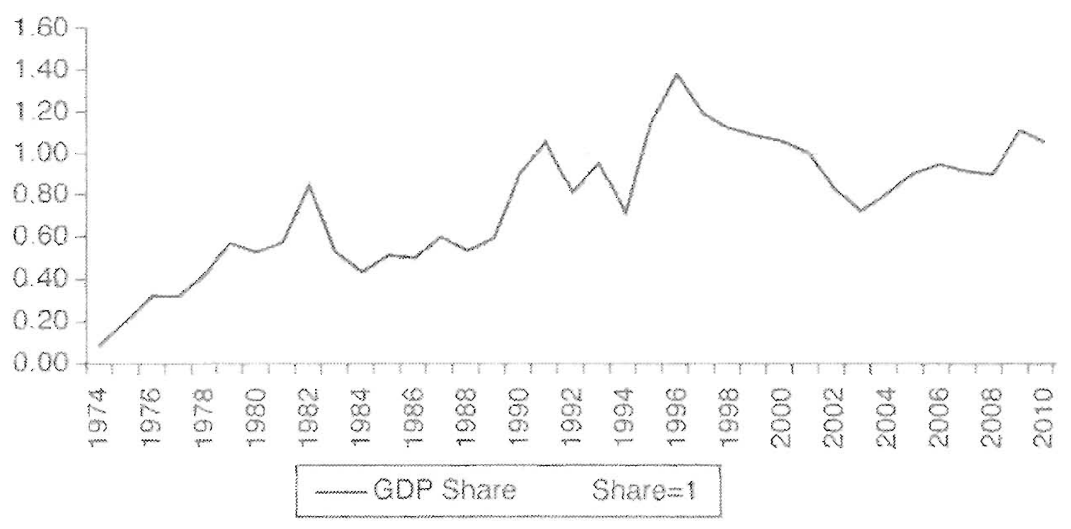

Figure 6.3 DMBRAMA expendmues as share of agriculural GDP Soune: Author. 
adjustments, and EMBRAPA's budget cuts were much less severe than those of other public organizations. This is a clear indication of the importance that economic a thonties in srant ascribe to EMBRAPA, in consideration of agricultural modemization.

The overall and itemwise trends in EMBRAPA's expendimues are shown in Figure 6.4 , divided between employees labor force; the second line from the top), capital costs (nvestments in captal ftems; the fourth line from the lop), and operational expenditures (day-today expenditures in support of research work; the third line from the top). Overall expenditures correspond to the Total' he in the figure (first line). The shape of this line is quite similar to that showing expenditures as a share of agricultual GDP (Figure 6.3 ), which is an additional argument in favor of the thesis that Brazil's federal govemment is sensitive to growth in the agriculture sector in allocating resources to EMBRAPA.

As already noted, budget culs did not touch researchers, and there were small increases in their numbers during the period of reduced budgets. This came at the expense of resources for capital and operan tional expenditures, reducing EMBRAPA's ability to carry out research. In some years, labor force expenditures came dangerously close to total expenditures. Recent government efforts, mainly from 2002 onward, have been devoted to overcoming this weakness in EMBRAPA's budget.

EMBRAPA is now the leader of the Ministry of Agrtoulture's agri cultural research system, with headquarters in Brasilia, 43 national

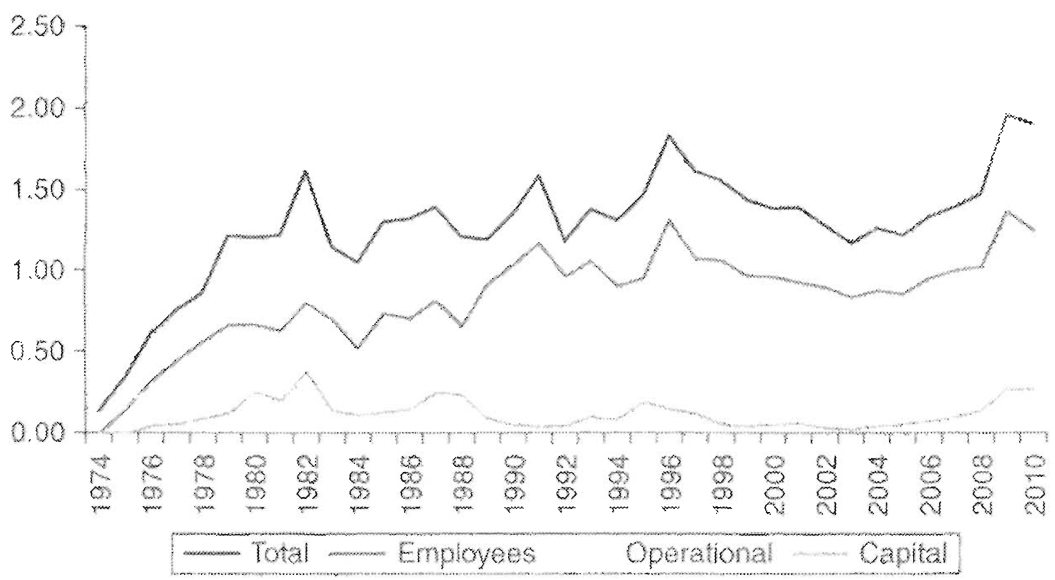

Figure 6.4 Trends in total and hem-wise EMBRAPA expenditures Seance: Auhor. 
research centers covering all areas of the nation, and 4 services units, for a total of 4 forganizational units. In addition to these, there are 14 business oflices. Outside. Brazil, there are 5 virtual laboratones (labex), In the Unted States, Gurope, and Asia, and 6 foreign offices, in Ghana, Mozambique, Mali, Senegal, Venezuela, and Panama. There are 17 state organizations associated with EMBRAPA, with research and extension mandates, and there are trequent parthershps with tederal, state and private miversties, NoOs, and private organizations, some of them mulinationals.

\subsection{Policies to develop Cerrado agriculture and the role of LMBRAPA}

The Cerrado accoumes for 25 percent of the area of Brazil, and is mainly fond in the Central-wast reglon. Up to the 1960 s extensive catte ranching was the dominm activity in the context of an underdevel oped agriculure. The soil is poor and acid, and spels of drought in the rany season are main risks facing the producton of grain. The conquest of the Cerado by modern agriculture is one of the most impontant achievements of agrarian sciences. It is not the objective of this section to repont the complete history of modern Cerado agriculture, but to note some facts that are relevant to Japan-Brazil agricultural research copperation in the Cerado.

Whe the maxguation of Brasila in 1960, the federal govermment unctertok the constructon of a rallroad and road grid linking the capital to the main citics of the Southem, Southeastem, Northeastem, and Vorthen regions. It bult airports and a communications intrastruc. ture. The federal goverment also created a very large program of oredu to support the improvement of the Cerado's soil and the development of moden agricultur. Population densty was very low in the Cerado, which was an advantage for farmer migraliom from the Sowthern and Southeastem regions. Compared to the local genmy, the mgrants were much more advanced in terms ot modern agricultural knowledge. They sold their smallholdings, bough larger areas, and setved them using moden agricultural technques. rew anong the local population 'moved up' to become modern tamers. Molem agncuhtural knowledge and an inclination to take risks motivated the migrants to search for advanced lechnologies in research centers and to take advantage of subsidied credit to support their work. The Cerado is thus a lypical case of agriculural development promoted by famers from more advanced agrom nomic culture, rather than the local population, and this is a point that 
cannot be overlooked in dealing with Africa. In this process, the locat population benefited from technology and experiences of those newly setted farmers.

Cerrado research ranked high as a research priority of EMBRADA, and still does so. EMBRAPA established important research centers in the Central-West region: in Brasilia, the Cerrado Agricultural Research Center (CPAC; specific to the Cerrado), the National Vegetable Research Center, the National Genetic Resource and Biotechnology Research Center, and the headquarters of EMBRAPA; outside Brasilia, the Rice and Bean National Research Center in Colania, and the Beef Cattle National Research Center in Campo Grande (MS). The Com and Sorghum National Research Center is outside the Central-West region, but within the Cerrato, in Sele Lagoas (MG). The Soybean National Research Center played a very important role in developing soybean varieties adapted to low latitudes such as the Brazilian Cerrado. and without them, the development of the Cerrado soybean crop would not have occurred. New wheat varieties adapted to the Cerrado also played an important role. The national research centers for soybeans and wheat are in the Sonthem region, in Londrina (PA), and Passo Fundo (RS), respectively. The Dairy Catte National Research Center, located in Juiz de Fora (MG), is also investing resources in improving milk production in the Cerrado. Moreover, the federal govemment established universities and Master's and Ph.D. programs in all the states in the Central-West region: Federal District, GO, TO, MG, and MS. It provided research incentives to universities and research institutes to find solutions to problems of the Cerrado, and hence a strong and diversified research network was created and developed in the Cerado region.

Collaborations with Japan, the United States, France, the World Bank, and the Inter-American Development Bank were very important, as well as whthe International Centers within the orbit of the CGIAR. The development of the Cerrado is a case of success in internationat cooperation: between governments, research institutions, universities, and international centers. But the Japanese cooperation was unique in the sense of institution building: of joining the researchers and resources of the two countries to develop a particular region. It was a case of copperation where the two sides worked together with the same objectives.

In the 1970 , high grain and meat prices were instrumental in the take-off of the Cerrado program. When prices fell, the development of the Cerrado was firmly on the way, without any chance of retreating. 


\subsection{EMBRAPA's challenges and the expected role of external cooperation}

This is the confext in which intematonal cooperation between EMBRAPA and multhateral and biateral agencies was carted out. The most relevant question here is whon and how external cooperation can be said to succed, which can be answered as follows.

(1) The recipient institution becomes prepared to face the challenges of its mandate, and learns to discover upcoming problems and how to solve them.

(2) At the end of the cooperation, the recipient institution learns to stand on iks own feet.

(3) The external and recipient institutions boln gatu by workng together.

Betore the stan of extemal copperation it is important to understand the problems of the reciplent institution. The following points must be looked at in formulating an institution bunding plan.

1) The bottenecks in the way of the external cooperation: these can include a lack of caunterpart hunds, and problems of legal and cultural origin.

(2) The goals of the institution.

(3) The problems of the institution, its challenges, and its capacity to ace therr.

(4) The conceptual basis of the institution, and how compatble this conceptual basis is with its goals.

(5) The organizational mode; how lexible it is, and how it adheres to the goals of the institution.

(6) The flexibily to manage the budget and to reallocate it to new demands.

(7) The Mexibixy to mange personel, and identification of legal and bureaucratic restrictions.

(8) The researther career path, the flexibuty to model $i$, and compet the wages and compensation.

(9) In hring, are equal rights guaranteed to those who apply for positions, and are selections based on merit? Are lack of mert and wrongdoing used to fustify dismissals?

(10) The ability to communicate with society at large, and its relation ship with the media and its clients. 
(11) The capacity to estabish research prionities.

(12) The capacity to tormulate a research program, considering budget restrictions, and the authority to carry it out.

(13) The competence to evaluate itself, to estmate the returns on its investments, and to communicate its results lo society, authorities, and important leaders.

(14) The capacity to convince govemment and the private sector to maintain and to increase its budget.

(15) The ability to relate to the world of politics based on the principles of mutual respect and independence.

(16) Hiring and promotions reward competence and loyalty to the institution.

(17) The selection of managers for research units rewards merit and managerial competence.

(18) The competence to relate to intemational research institutions, universities, and the private sector.

(19) The potential to rewin outstanding researchers on the staft.

(20) Physical infrastructure: buildings, laboratories, expermental helds, etc.

In this regard, the concept of institution building is considered to be particularly important. Wedistinguish two different concepts: Institution buiding reters to a set of actions that are performed to change the structure of an organization, or to add to its capacity to do more of the same things in the same way. One example of the latter case is when laboratory equipment is supplied by a donor country.

In the first case, there may be changes in the organizational model, in the processes of setting priorities, planning, executing research plans, conducting evaluations, and diffusing research results. It may involve seting researcher career paths, promotions, and wages so as to reward competent work and to stmulate talented researchers. It may he necessary to strengthen the capacity of the organization to communicate with budget authorities, and with executive and legislative powers, or it may be a case of improving communications with the media at the local, regional, and national levels. The relationship with private research or with international institutions may need attention, or infrastructure may be lacking or require reforms. Which of these items receive attention depends on the nature of the problem, on the recipient institution, and on the amount of money that will be invested in the cooperation. An extreme case would be one involving ar all-encompassing change by which a new institution emerges, and this was the case with EMBRAPA. Such extreme cases are 
rare: it is more common to change selected points in the structure of ar organization. One interesting case is to center the cooperation in a few research units, and to focus it within a region. The JCA-EMBRADA COOperation focused on the Cerado and was concentrated in a few EMBRAPA research units and state research and extension organizations.

In the second case noted above, human or financial resources are provided to enlance the capacity of an organization to do more of the same things in the same way: the structure of the organization is not changed. This is weaker sype of institution building, which involves enlarging the capacity of an institution to do research, without changing its quality. In the real world, the wo ypes are present at the same time. If the institution is mature, more weight will be placed on the second case; however, the first case is mote common.

In every institution, small changes are always occuring, and they may be postive or negative in character. However, by 'institution building' we mean purposeful changes designed to improve the organization, and they are visible and sizable. Institution buiding may exist with or whthout axtemal cooperation; for instance, the decision fo transtom National Agriculural Research Deparment (DNPEA) into EMBRAPA beinged exclusively to Brazl. After its inauguration, EMBRADA sought technical and financial assistance from many places; international banks, other countries, research institutions, universities in Brazil and abroad, and Brazilian financial institutions, via Studies and Project Finance Organizations (FNEPs).

\subsection{Types of external cooperation from an institution building perspective}

Two types of extemal cooperation can be distinguished, as detailed below.

\section{(a) Joining institutions}

The cooperation agency (comtry, institution, etc.) sends staff that join the staff of the recipient organization under its rules of administration. Specialized coordination may exist to laciltate communication between foreigners and local nationals, and among the Coreigners themselves. From that point on, all activities are jointly planned and carried out: as if there were an informal merging of the agencies into a unque institution for the purpose of the objecUves of the cooperation profect. The results of the joint work belong to both parties: it makes no sense to try to separate them. There 
are many spillover effects from one party to the other, which work against splitting the outcomes of the project.

Cooperation encompasses external and internal funds: the counterpart funds. In general, the research program is carried out in the recipient country; if convenient, part of it can be performed in the donor country, or even in third countries. The training program may be carried out in the recipient or in the donor country; the latter applies, in general, to graduate traning. For the acquisition of laboralory and other types of equipment, the donor part of the budget may be imported, and part may be acquired locally. The cooperation program may concentrate on research, or it may move up a step turther to take care of technology transters or even investments that lacilitate the adoption of technology by farmers, such as electricity and irrigation. If the copperation succeeds, its benefts extend far beyond the end of the agreement. There are also spillover effects into regions not included in the original agreement. A careful evaluation of the project requires looking into its results at the end of the agreement and also far allead in time, in the defined region and in other regions that may have partaken of the benefits. There are two types of result: insthutional development, by which the recipient institution becomes prepared to face present and future challenges; and research results. They are designed to solve larmers problems and to modemize agriculture. Therefore. the evaluation of the project cannot overlook institutional development, the new technology it helped to develop, and the adoption of such technology by farmers. The JICA-EMBRAPA project exenplifies the joint type of cooperation, from which EMBRAPA, the Cerrado, and Brazil all profited. 3

\section{(b) Speciallzed cooperation}

Most external cooperation is specialized in themes, and does not join, in an informal way, two instifutions for the purpose of carrying out the terms of an agreement. It may be a case in which a foreign university opens its doors to receive graduate students, and the program expenses may be paid by a grant from the donor county. by the recipient country, or by a loan from international banks. At its own cost, the donor comntry may send scientists to deal with specific problems of the recipient institution, and the technical assistance that lollows may be of a shor - or long-term nature. There may be an agreement beween wo countries according to which the developing country can post a group ot senior scientists to the developed country to work with counterpart scientists, under the umbrella of 
specthe organizations. This is the case of the Brazlian labex expe rience, which can address research problems of mutual interest to the wo countries. However, an agreement may not drectly involve monetary expenditures: for instance, when wo institutions, one in the beveloping country and the other in the developed country, open their doors 10 allow the exchange of experience among scienbists va the heter and other means of communication.

Extemal comperaton of both types has been very important to the devel opment of EMBRARA and in particular to the development of reseamh for the Cemado. Of panticular significance have been the Japanese, Amenicam, and French cooperation, that of the International Centers rewolving around CGIAR, and that of intemational banks, the wond Bank and IDB. Except for the Japanese experience, all of these were of the specialized type, in the sense that they emphasized themes and did not Join with EMBRAPA in Brazil to solve a set of research problems.

\subsection{Distinctive characteristics of the EMBRAPA-Japan cooperation and ths results}

Up to 1970 the expansion of agriculure took place in regions where the exing knowledge of agncuhual practice could be applied, if necessary wht lew modificatons, but at the beginning of the 1970 s most of that type of land had been explored. The Cerrado and the Amazon region were the cholces for expanding agriculure, and traditional knowledge and technology would have alled there. Hence, at that lime, the expan sion of agriculure required investments in science and technology: facts well understood by the Brazhan govemment.

At the same time, the supply of food lagged behind the growth of demand, and consequenty at severe food crisis emerged in the cities. Fumbemore, the country needed to increase its exports to pay inter national debts brought about by industrialization polices. To increase tood exports, for which the intenational prospects were excelent, the country needed to increase its smphus over domestic consumplion. Thus, domestic consumption and food for export pointed to the importance of expanding agricultural production, and traditional technology was powertess to reach that goal. mporting the technology of the advanced combles would have falle, too, because technology is locally specific. The solution was to invest heavily in the generation of knowledge, which resulted in the creation of EMBRAPA, inaugurated on April 26 , 1973 (Alves. 2012 ). 
Soon after the inaugutation of EMBRABA, its leadership understood the need to shorten the road to results, because of the strong pressure from sockety and the govermment. No other way existed than to use the knowledge of agrarian science accumulated in the developed countries to generate technology uschul for Brazilian agriculwre. Fortunately, EMBRAPA found the doors open for this type of cooperation. Developed commies, their universities, research institutes, and the intemational banks understood the importance of developing Brazllan agriculture and signed copperation agreements. In the case of the Cemado, however, EMBRAPA saw the meed for a diferent type of cooperation that would go far beyond the specialized type of instutun bulding into the intomal merging of two institutions, one of which would be EMBRAPA and the other a foreign institution that would jointy work in Brazil to develop technology for the region. The government and EMBRAPA understood that the best choice was Japanese coperation; this cooperation was requested by the Brazihan government soon after EMBRAPA's inauguration in 1973, and the technical cooperation started in 1977. The reasons for choosing Japanese cooperation were as follows.

(a) Technical assistance should consider research, extension, and linancial resources to develop the Cerrado. It should extend beyond the development of research, and institutional bulding must incorporate those activities, and JICA was willng to do this.

(b) Japanese research was very strong in agrarian science: in land saving technology, in irrigation, and in the development of small-scale equipment and machinery for the mechanization of agriculture.

(c) Japan was a major importer of food and its imports were rising.

(d) Japan wanted to dversify the sources of its food supply, and Brazil ofered good prospects.

(e) The Japanese-Brazilan populaton (induding their descendants) was large enough to fachlitate the lwes of Japanese researchers and probssionals in Brazil.

(f) MCA's model of work and of technical assistance was flexible to the point of neeting EMBRAPA's expectations of joint work.

(g) Agrarian sciences were well developed in some Japanese universities, which was an important point for the EMBRAPA training progxam.

(h) Japanese industry was very advanced in producing top research equipment. The government of Japan agreed to provide funds for the acquisition of research equipment. They allowed researchers to ask new questions and answered them without loss of time, therefore saving EMBRAPA's scarcest resource: researcher time. 


\section{4 bisendives}

(1) EMBRAPA was a mature insthution, well integrated in the develop. ment policies of the Brazilian govemment, and conscious of its role to develop Brazilan agriculture, of its weaknesses, and of the need for technical assistance.

(1) Finally, IICA expressed its willngness and demonstrated its readiness to sign an agrement to experiment in an all-inclustre program of technical assistance to develop the Cerrado.

The Brazil-hapan cooperation embraced research, extension, rumal credit, and investments in electrication and irrigation. The detals will not be covered here, since there is an excellent report that explains the concept of the project and how il was carried out, and evaluates the results."

The strongest points of Japanese cooperation from the standpoint of institution buhding were: the group of outstanding researchers and dedicated assistants that came to EMBRAPA, and fomed a hamonious group with EMBRAPA researchers to carry out the research progran; the lraining progran in Japanese universites; the lop-quality laboratory equimment that saved much researcher the and extended the questions hat cond not be previously answered; the support for exterision work, research on the enviroment, soils, plants, anmal diseases and msect control, and plant breeding; the work with research and extension organizations in MG, BA, MT and GO; and rural credit, electrication and irrigation financing. Most of all, thanks to the Japanese copperation, EMBRAPA research wnits greatly improved their abilty to answer the problems of the Cerado.

The Cerrado Agricultural Research Center ICPC, Cenho de Pesquisa Agropecuária dos Ccrados) owes much of what it has acheved to the Japanese cooperation. The cooperation was also important for the develomment of other researchers units, such as the Soybean Center (Centro Nacional te Pesquisa de Soja), Vegelable Center (Centro Nacional de Pesquisas de Hortalicas), and Cenargen (Centro Nacional de Recursos Geneticos e Biotecnologia).

Clearly, not all the success of the project can be atmbuted to the Japanese cooperation, but the joint project was hudamental in devel. oping EMBRAPA's research capacity, and the technology generated by EMBRAPA paved he way for the growth of production in the Cerrado.

\subsection{Koncluding remarks}

lapanese cooperaton has been very useful to LMBRAPA development. I: helped to build Cerado research, and the research results contributed 
to the development of agriculture in the region. In terms of the total Cerrado share of the national population and land area, Cerrado agriculture has perfomed very well. Since the data indicate a pattern of development largely based on productivity improvement, it is clear that new technology was the main driving torce of development. Moreover, the increase in yidds saved land. In this sense, the development of the Cerrado has been friendly to the environment (Martha et al, 2012).

The full impact of Japanese cooperation had much to do with the CPAC. Under the joint leadership of CPAC JICA, the cooperation extended to other EMBRAI'A units and state research organizations. If succeded in generating the technology needed to modernize agriculture and is an excellent example of institution bulding, by which two countres join human and financial resources, focused on one research unit and on a specific region - the Certado-under a unified command. Japanese cooperation was all-inchusive: it dealt with EMBRAPA institution bulding; it joined Brazil in creating the implementation body CAMPO, and this company was instrumental in extension work and in settement projects. JCA financed electrification and ixrigation programs. The fact that the program encompassed all the activies required to acheve the development goals - research, extension, implementation of settement projects, electrfication, and irrigation financing-explains its successes.

One important point attracts attention: the two countries were ready to cooperate; Brazil needed to expand its agricultural output with the minimum impact on the area under cultivation, and Japan wanted to diversify its imponts. The lapanese style of cooperation and expertise recognized the importance of institution building. As a consequence of the join work, EMBRAPA is now competent to bace new challenges; it has learned more in order to solve problems by itself; and both IICA and EMBRAPA have experienced immense gains.

\section{Notes}

1. This section is based on Alves (2012).

2. Up to 1973, there was a research institution in the Ministry af Agriculture (now MAl'A): the National Agricultural Research Department (DNDEA). The govemment decided to subject it to an all-encompassing reform progxam, from the organizational bodel to phaning and exesting reseanth and lechnology difusion. This reform created IMBRAPA.

3. In this spirt, at beginning of the 1960 s, Purdue and the Federal University of Viçosa signed an agreement to develop a graduate program, which was financed by USAD and the ford Foundation, and was extended to other universlies 
156 Eliseu Alves

4. MAPA and JICA (2002) JapantBranh Agrintum Develoment Cooperation Programs in the Cerato Region of Brazil: Jomk Evoluation Shuly (Brasilia and Tokvo: MAls and $[(\mathrm{CA})$.

5. What the author can do beyond a report from the vantage point of 2011 is to contim the real success of the cooperation in instituton building and to add indirect evidence about the growth of Cerado agriculure, which excecds that of brazil as a whole in the case of grains, tomatoes, and beef and dairy catle, and which has had good pertomance in carrots and potatoes, as representatives of vegetable crops.

\section{References}

Aves, Hiscu (2012) EMBRAPA: 'A successul case of institutional innovation' in G.B. Martha Jr, and I.B. de Sowa Ferretra Who (eds), Brazhian Agrioume: Development and Changes (Brasilla: EMBRAMA), pp. 143-160. (This article is a revised version of an article of the same title published in Revista de Poltica Agricola, year XIX, special edition, Iuly 2010, p . $64-72$.

Martha, G.B., Jr. E. Alves, and E. Contini (2012) 'Land-saving approaches and beef production growth in Brazil.' Agrikulum Systms, 110, pp. 173-177. 